\title{
Carbon Footprint and Feedstock Quality of a Real Biomass Power Plant Fed with Forestry and Agricultural Residues
}

\author{
Alessio Ilari (D), Daniele Duca (D), Kofi Armah Boakye-Yiadom (D), Thomas Gasperini and Giuseppe Toscano * (D) \\ Department of Agricultural, Food and Environmental Sciences, Università Politecnica delle Marche, Via Brecce \\ Bianche 10, 60131 Ancona, Italy; a.ilari@staff.univpm.it (A.I.); d.duca@staff.univpm.it (D.D.); \\ k.boakye-yiadom@pm.univpm.it (K.A.B.-Y.); thomas.gasp@yahoo.it (T.G.) \\ * Correspondence: g.toscano@staff.univpm.it; Tel.: +39-071-2204918
}

Citation: Ilari, A.; Duca, D.; Boakye-Yiadom, K.A.; Gasperini, T.; Toscano, G. Carbon Footprint and Feedstock Quality of a Real Biomass Power Plant Fed with Forestry and Agricultural Residues. Resources 2022 11, 7. https://doi.org/10.3390/ resources11020007

Academic Editor: Elena Rada

Received: 17 December 2021

Accepted: 16 January 2022

Published: 18 January 2022

Publisher's Note: MDPI stays neutral with regard to jurisdictional claims in published maps and institutional affiliations.

Copyright: (C) 2022 by the authors. Licensee MDPI, Basel, Switzerland. This article is an open access article distributed under the terms and conditions of the Creative Commons Attribution (CC BY) license (https:// creativecommons.org/licenses/by/ $4.0 /)$.

\begin{abstract}
Phasing out fossil fuels to renewables is currently a global priority due to the climate change threat. Advocacy for biomass use as an energy source requires assessing the quality biomass and ecological impacts of bioenergy supply chains. This study evaluated the quality of biomass residues from orchards and silviculture transported from different Northern and Central Italy locations and the carbon footprint of a biomass power plant. The total greenhouse emissions were calculated based on primary data for 2017 according to the ISO/TS 14067. All the residue samples showed their suitability for biofuel use. Ash content was relatively low on average (3-5\% d.m.), except for grapevine residues (18\% d.m.). The lower heating value was within the expected range of $15-21 \mathrm{MJ} \mathrm{kg}^{-1}$ for plant species. The average GHG emission from the power plant was $17.4 \mathrm{~g} \mathrm{CO}_{2} \mathrm{eq} . / \mathrm{MJ}$ of electrical energy, with the energy conversion (38\%) and transportation of biomass (34\%) phases being the main impact contributors. For this study, impacts of residual agricultural residue were about half that of residues from forest management, mainly due to chipping and greater transport distance. Results show that sourcing residual biomass materials for electricity generation close to power plants significantly reduce GHG emissions compared to conventional fossil fuels.
\end{abstract}

Keywords: residues; energy; sustainability; wood; carbon savings; green; global warming; climate change

\section{Introduction}

The threat of climate change and the need to ensure environmental sustainability has become a global agenda. Emissions from anthropic activities are considered the main driver for warming the planet [1]. The IPCC 2021 report indicates that the global surface temperature rose by $1.10{ }^{\circ} \mathrm{C}$ between 2000 and 2020 [2]. Extreme weather events are projected to increase, posing a threat to ecological, economic, and social sustainability. Current severe challenges of climate change include the emission of high amounts of greenhouse gases (GHG), the depletion of non-renewable resources, and the increasing amount of waste [3]. Thus, there are concerted efforts globally to find solutions that will prevent and mitigate these challenges.

The energy sector is the most predominant sector responsible for climate change. Global energy-related $\mathrm{CO}_{2}$ emissions are heading for their second-largest annual increase ever, with the energy sector estimated to be responsible for $73 \%$ of $\mathrm{CO}_{2}$ emissions [4]. The electricity and heat sector contributes significantly to GHG emissions and accounts for about $44 \%$ of energy sector emissions [5]. According to Enerdata, Europe is the thirdlargest energy consumer behind Asia and North America [6]. Thus, the EU, in its quest to achieve net-zero $\mathrm{CO}_{2}$ emissions coupled with a significant reduction in other GHG emissions, has implemented several actions to be taken. Some of these actions include: maximizing energy efficiency, maximizing the use of renewable energy sources, circular economy implementation, tackling residual $\mathrm{CO}_{2}$ emissions through carbon capture and 
storage [7-9]. The relative contributions of different fossil fuels to total energy-related $\mathrm{CO}_{2}$ emissions appear to change over time [4,6]. Petroleum which accounted for $40 \%$ of global energy-related $\mathrm{CO}_{2}$ in 2004, is projected to decline to $36 \%$ in 2030. However, natural gas combustion and coal should increase from $20 \%$ and $39 \%$ to $21 \%$ and $43 \%$ in 2030 , respectively. Considering coal is the most carbon-intensive of fossil fuels, this poses an environmental challenge [5]. The energy sector was responsible for about $80 \%$ of GHG emissions produced in the EU in 2018. However, owing to the COVID-19 global pandemic, energy consumption fell by $4 \%$ in 2020 due to lockdown measures and transport restrictions. The same was valid for global energy production, which fell by $6 \%$ in 2020 [6]. For instance, primary energy consumption in Italy reduced from 149 Mtoe in 2019 to 137 Mtoe in 2020, while energy production increased from 34 Mtoe to $35 \mathrm{Mtoe}$ for the same period [6]. The situation has returned to normalcy in 2021 due to emerging markets with global energy demand projected to increase by $4.6 \%$ [4].

There is a surge in need for new systems for renewable energy generation worldwide. The over-exploitation, decrease in availability, growing difficulty in supply, and increased sensitivity to energy-environment dimensions of fossil fuels, such as oil and natural gas, have facilitated the advocacy for renewable energy sources [10]. Renewables are in fourth place after oil, coal, and natural gas in global quantitative production [11]. The EU has implemented several energy policies to promote renewable energy from renewable sources with a $20 \%$ renewable energy target by 2020 [9] and is currently discussing reaching a $40 \%$ by 2030. Among renewable energy sources, biomass could reduce the net GHG emitted per unit of electricity generated and be interesting for energy generation for domestic use near the biomass farm, including biogas for transportation [12-15]. Biomass generally refers to the biodegradable fraction of products, waste, and residues of biological origin from agriculture, forestry, and related industries [9]. It is a versatile source that can generate heat, electricity, and liquid biofuels [16]. However, to advocate for extensive biomass use as an energy source, it is crucial to assess the ecological impacts of biomass cultivation through land-use changes, including displacement, the introduction of invasive alien species, and other effects on biodiversity, food production, and climate change.

According to 2014 data from ISTAT and the Ministry of Economic Development (MISE) in Italy, the gross domestic consumption of energy amounted to 172.99 Mtoe, of which 142.83 Mtoe imported from abroad, equivalent to $82.5 \%$ of total consumption [10]. The agroenergy supply chain in Italy is an evolving sector, mostly directly related to agriculture and forest biomass that serve as fuel for electricity and heat generation. Between 2000 and 2020, electricity generation from primary solid biofuels has increased significantly from $425 \mathrm{GWh}$ to $4430 \mathrm{GWh}$ in Italy [17]. Renewable sources contribute $45 \%$ to the current national energy mix used to produce electricity fed into the Italian electricity system. From an energy point of view, this is of interest due to its potential for significant $\mathrm{CO}_{2}$ emission savings compared to fossil fuels and net-zero $\mathrm{CO}_{2}$ neutrality. Solid biomass, sometimes regarded as waste, is considered less expensive economically. Therefore, with increasing global and local energy requirements and the urgent need to decrease the percentage of energy products purchased abroad, woody biomass presents a viable opportunity to be harnessed.

Although European and national policies promote the use of residual biomass materials for electricity generation, it is essential to consider the quality and characteristics of these materials. The low quality of biomass, often defined in its inherent features (high moisture content, low energy density, low bulk density, varying size, and shape), hinders its full exploitation [18]. The motivations to assess solid biofuel properties include economic, technical, and environmental reasons. Woody biomass residues are generally heterogeneous and may originate from branches, stem wood, barks, and leaves of different species. The dissimilarities in physical properties and chemical composition can affect a biomass power plant's combustion efficiency, maintenance, and logistics, partly limiting its energy and environmental sustainability [19]. Therefore, it is imperative to implement an adequate system to monitor and discriminate solid biofuel quality used in power plants. Biofuel quality control of physical characteristics such as particle size, bulk density, moisture content, net 
calorific value, and chemical composition such as ash content is essential for power plants and other stakeholders. Ash content indirectly contributes to dust emission and operational problems such as fouling, slagging, and corrosion $[20,21]$, based on the ash chemical composition and specific chemical elements such as chloride $(\mathrm{Cl})$ and sulfur $(\mathrm{S})$ [22]. In addition to nitrogen content $(\mathrm{N})$, these elements undergo reactions to form emitted pollutants, such as nitrogen oxides, sulfur dioxide, and hydrogen chloride [21].

The burgeoning interest in sustainability reporting has enhanced economic, environmental, and social development communication. Environmental sustainability assessment studies have become paramount in providing accurate and reliable information to help address the climate change challenge. The Life Cycle Assessment (LCA) is a measurement tool recognized internationally for performing environmental impact assessment studies [23]. The carbon footprint of products (CFP), a specific ecological impact assessment for greenhouse gas emissions, on energy production and consumption have increased steadily over the past decade, particularly in the EU [24]. Companies are encouraged to report impacts related to their activities in the energy sector. Energy companies rely on impact assessment studies to highlight environmental hotspots along their production chains to develop mitigation strategies for improvement. Impact assessment studies are currently available on energy production from different sources. Most of these studies focused on impacts associated with coal power plants [25-28]; others concentrated on solar power plants [29,30], hydropower plants [31-33], geothermal power plants [34-37], and natural gas [38]. Medeiros et al. [39] also assessed the carbon footprint of energy generation from microalgae biomass.

As mentioned earlier, the LCA studies have extensively assessed the environmental impacts of various biomass scenarios. However, the wide variability in system boundaries require more in-depth studies. Insights on the effects of large biomass power plant operations, considering the quality of biomass material, processing of different biomass materials, the transportation of the biomass material, and the pre-treatment of the material, are needed. Although quantifying and analyzing the environmental burden of energy generation from biomass sources is essential, it has not been sufficiently explored in Italy. Using residual woody biomass, otherwise considered a waste, as valuable raw material for power plants is necessary for a circular economy. Therefore, this study aims to assess the residual biomass quality and carbon footprint of an actual biomass powerplant in Italy, specifically related to virgin and residual wood biomass and agricultural residue as fuel for electricity production. The goal is to characterize the carbon footprint of power production by valorizing biomass streams of low quality of vast territorial distribution, identifying possible hotspots, and suggesting improvement options to enhance the efficiency of the energy production chain.

\section{Materials and Methods}

This chapter is divided into two main parts. The first section covers assessing the physical and chemical characteristics of the residual biomass materials used by the power plant company. The second section describes the carbon footprint assessment of the company based on the life cycle approach. Further details are provided below.

\subsection{Biomass Quality and Characterization}

\subsubsection{Biomass Material}

The power plant company processes different biomass materials from various sources and places. According to the company, the residual biomass materials are distinguished based on plant species, the part of the plant used, or the particle size, as shown in Table 1. 
Table 1. Classification and description of residual biomass materials.

\begin{tabular}{lll}
\hline Classification & Biomass Typology & Description \\
\hline Particle size & Bulk & Non-chipped wood \\
& Wood chips & Chipped wood \\
& Roots & Non-chipped tree roots \\
& Pre-ground & Semi-ground material \\
& Mixed ground & Ground and related material \\
Origin (Vegetable) & Orchard & Residues from orchards (apple, pear, etc.) \\
& Vine & Residues from the vineyard (pruning and vineyard explant) \\
& Mixed orchard and vine & Residues from orchard and vineyard \\
Origin (Forest) & Conifer & Softwood tree residues from forest management \\
& Poplar & Woodchips from poplar cultivation and management \\
& Hardwood & Broad-leaved tree residues from forest management \\
& Precious wood chips & Woodchips of high quality \\
\hline
\end{tabular}

\subsubsection{Quality Analysis on the Biomass Materials}

The biomass quality and characterization assessment were carried out on more than one hundred samples provided by the power plant. The quality of the collected samples was established by measuring moisture content, high heating value (HHV), ash content, carbon, hydrogen, nitrogen content, oxygen content, chlorine, and sulfur due to their influence on economic, environmental, and energy aspects. All analyses were carried out following current ISO standards on solid biofuel characterization and have been summarized in Table 2. Lower Heating value was calculated from HHV, hydrogen content, and moisture content.

The analyses were performed at the Biomass Lab of Università Politecnica delle Marche (www.biomasslab.it, accessed on 1 December 2021).

Table 2. Proximate and ultimate analyses of biomass materials with corresponding reference methods.

\begin{tabular}{|c|c|c|c|}
\hline Analysis & Instrument & Reference Method & Brief Description \\
\hline Sample preparation & $\begin{array}{l}\text { Cutting mill RETSCH } \\
\text { SM } 2000 \text { Moisture }\end{array}$ & ISO $14780[40]$ & $\begin{array}{l}\text { The sample is stabilized in an oven at } 40^{\circ} \mathrm{C} \text { for about } \\
24 \mathrm{~h} \text {, then milled to obtain a particle size } \\
\text { distribution }<1 \mathrm{~mm} \text {. }\end{array}$ \\
\hline Moisture content & $\begin{array}{l}\text { Ventilated stove “MPM } \\
\text { Instruments" type M } \\
\text { 250-VF, Electronic scale }\end{array}$ & ISO 18134 [41] & $\begin{array}{l}\text { A sample of about } 300 \mathrm{~g} \text { is weighed and set in an oven } \\
\left(105^{\circ} \mathrm{C} \text { for } 24 \mathrm{~h}\right) \text { until it reaches a constant weight. The } \\
\text { percentage of evaporated water is the result. }\end{array}$ \\
\hline $\begin{array}{l}\text { Higher Heating } \\
\text { value }(\mathrm{HHV})\end{array}$ & $\begin{array}{l}\text { Isoperibolic calorimeter } \\
\text { (mod.C2000 basic, IKA) }\end{array}$ & ISO 18125 [42] & $\begin{array}{l}\text { Under specified conditions, a sample of mass } \\
(1.0 \pm 0.2) \mathrm{g} \text { was burned in high-pressure oxygen in a } \\
\text { bomb calorimeter }\end{array}$ \\
\hline Ash content & $\begin{array}{l}\text { Ash analyzer TGA } \\
701 \text { LECO }\end{array}$ & ISO 18122 [43] & $\begin{array}{l}\text { About } 1 \mathrm{~g} \text { of milled material is weighed and brought } \\
\text { to incineration through three steps-105, } 250 \text {, and } \\
550{ }^{\circ} \mathrm{C}-\text { in an oxidizing atmosphere until it reaches a } \\
\text { constant weight. The inorganic fraction of the starting } \\
\text { material is the remaining mass after the process. }\end{array}$ \\
\hline Carbon content & $\begin{array}{l}\text { Perkin Elmer mod. } \\
2400 \text { Series II CHNS/O } \\
\text { system }\end{array}$ & ISO 16948 [44] & $\begin{array}{l}4 \text { mg of the sample are oxidized at about } 900{ }^{\circ} \mathrm{C} \text {. The } \\
\text { combustion gases are then reduced to analyzable } \\
\text { compounds, which are adsorbed in a gas } \\
\text { chromatography column. The measurement takes } \\
\text { place using a thermal conductivity detector (TCD). }\end{array}$ \\
\hline Hydrogen content & $\begin{array}{l}\text { Perkin Elmer mod. } \\
2400 \text { Series II CHNS/O } \\
\text { system }\end{array}$ & ISO 16948 [44] & See Carbon content analysis. \\
\hline Nitrogen content & N analyzer FP-528 LECO & ISO 16948 [44] & $\begin{array}{l}\text { By-products of combustion of about } 0.10 \mathrm{~g} \text { of milled } \\
\text { material pass through a furnace filter and a } \\
\text { thermoelectric cooler for subsequent collection in a } \\
\text { ballast apparatus and then measured by the thermal } \\
\text { conductivity cell for nitrogen. }\end{array}$ \\
\hline
\end{tabular}


Table 2. Cont.

\begin{tabular}{|c|c|c|c|}
\hline Analysis & Instrument & Reference Method & Brief Description \\
\hline Oxygen content & $\begin{array}{l}\text { Perkin Elmer mod. } \\
2400 \text { Series II CHNS/O } \\
\text { system }\end{array}$ & ISO 16948 [44] & $\begin{array}{l}\text { The weight fraction of oxygen is determined by } \\
\text { difference using the equation: } \\
O=100-(C+H+N+S) \text { as indicated } \\
\text { in the standard. }\end{array}$ \\
\hline Chlorine content & $\begin{array}{l}\text { Liquid ion } \\
\text { chromatographer (mod. } \\
761 \text { COMPACT IC, } \\
\text { Metrohm). }\end{array}$ & ISO 16994 [45] & $\begin{array}{l}\text { Samples were decomposed in a calorimetric bomb } \\
\text { with excess oxygen and absorption of acid combustion } \\
\text { gases in water }\left(1 \mathrm{~cm}^{3}\right) \text {. Chloride was detected by } \\
\text { liquid ion chromatography. }\end{array}$ \\
\hline Sulfur content & $\begin{array}{l}\text { Liquid ion } \\
\text { chromatographer (mod. } \\
761 \text { COMPACT IC, } \\
\text { Metrohm). }\end{array}$ & ISO 16994 [45] & $\begin{array}{l}\text { Decomposition in calorimetric bomb with excess } \\
\text { oxygen and absorption of acid combustion gases in } \\
\text { water }\left(1 \mathrm{~cm}^{3}\right) \text {. Sulfate was detected by liquid ion } \\
\text { chromatography }\end{array}$ \\
\hline
\end{tabular}

\subsection{Carbon Footprint Assessment}

The Carbon Footprint of Products (CFP) measures the total GHG emissions directly or indirectly caused by an activity or accumulated over a product's life stages [46]. It is expressed as $\mathrm{CO}_{2}$ equivalents and based on a life cycle assessment using the simple impact category of climate change. The CFP methodology follows the ISO 14067 standard [47]. Life cycle assessment (LCA) is a standardized scientific methodology for assessing the impacts related to the life cycle of a product or service. The LCA concept consists of four main interrelated phases, goal and scope definition, Life Cycle Inventory (LCI), Life Cycle Impact Assessment (LCIA), and Interpretation, following the ISO 14040/14044 standards [48,49]. The LCA is an iterative and flexible tool that allows for modifications in the different phases until the final objective is satisfied. This present study's methodology, data, and assumptions are detailed in the following sections. The case study was treated using the carbon footprint method.

\subsubsection{Description of the Company}

The company, San Marco Bioenergie (SMB) Spa, is a member of the Bioenergie group and manages the biomass power plant in Bando d'Argenta in the province of Ferrara, Emilia-Romagna region, Italy. The company aims to distribute energy produced from renewable sources for sustainable energy development. With an estimated $23 \mathrm{MW}$ net of installed power, the plant at Bando is the largest biomass plant in Northern and Central Italy. It is one of the most efficient plants, producing net electricity with over $25 \%$ efficiency. Its annual energy production of about 180,000 MWh is equivalent to the requirements of approximately 27,000 inhabitants. The power plant includes two identical units with a net electric capacity of about 10 MWe each; the boiler technology is based on an air-cooled grate and a steam generator with a nominal capacity of 46 ton/h of superheated steam. The associated steam turbine is a full condensation type with an air-cooled generator. Both lines are equipped with a superheated steam generator, a steam turbine, and a connected electric generator and systems to reduce atmospheric emissions in line with the most advanced technology available (BAT). The biomass used for combustion is virgin and of vegetable origins. The biomass is the residue of specially cultivated fruit plants, woodland, and poplar maintenance. The plant has rigorous and innovative procedures for origin qualification and biomass acceptance, defined according to the kind of biomass supplied.

\subsubsection{Goal and Scope Definition}

The study's goal is to determine the potential contribution of the SMB renewable electricity production chain to the global warming impact category (GWP) and form the basis for identifying possible improvement strategies. This contribution is quantified by assessing greenhouse gases (GHG) emissions which are emitted directly or indirectly during the life cycle. The intended use in the medium term is to quantify the product's 
sustainability and provide valuable information to the client to evaluate initiatives to reduce the calculated impact and thus increase the environmental sustainability of their productions. End-users of this study are the client, any clients who purchase the product under analysis, and any other stakeholder involved to varying degrees in the production, processing, and distribution of the asset itself and interested in aspects of sustainability.

The scope of this study is the carbon footprint, defined as the total carbon emissions from the entire life cycle of products and services related to the SMB renewable electricity production chain, according to the boundaries defined in the sections below.

\subsubsection{System Boundary}

The production system analysis can be divided into four main phases, each characterized by incoming and outgoing flows and specific operations, as shown in Figure 1. The system boundaries indicate which unitary processes (and related flows) fall within the analysis conducted. Data from all phases were considered, including the impact due to the production and transport of all the inputs present in the supply chain (fuels, electricity, chemicals, etc.). The approach used is the "cradle to gate" type (from the cradle to the company gate) and considers the ash disposal phase within the system.

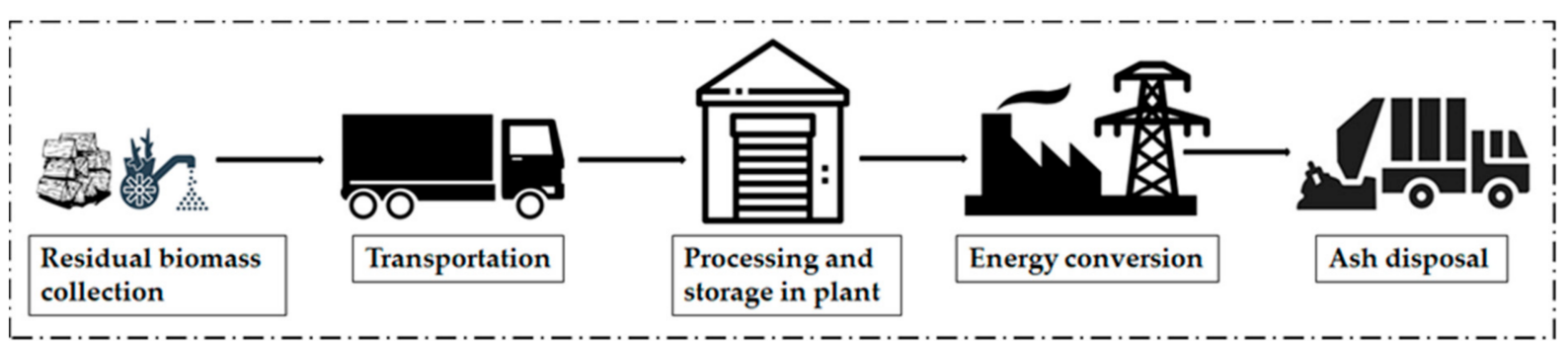

Figure 1. The system boundary of the phases considered for electricity generation from woody and vegetable biomass.

\subsubsection{Functional Unit}

Following other industry studies and technical regulations, the $1 \mathrm{MJ}$ of renewable electricity SMB is the chosen functional unit. The functional unit (FU) is the reference basis for mathematical calculations regarding the impacts of the flows into and out of the defined system. As established by the reference standards, the FU must be consistent with the study's goal.

\subsubsection{Transportation to the Company}

Biomass material in the form of wood chips or pre-ground is transported from the field to the plant. The residual biomass materials were transported from different provinces in Italy's north and central parts to the power plant located in the Emilia-Romagna region. Trentino-Alto Adige, Friuli-Venezia Giulia, Lombardia, Veneto, Emilia-Romagna, Toscana, Marche were the regions the residual materials were obtained from, as shown in Figure 2. Tractors with a semi-trailer walking floor system having a loading volume of $92 \mathrm{~m}^{3}$ are used to transport wood chips. The standard tractors used are DAF XF 510 (euro 6); MAN 480 (euro 6). A truck + trailer system, generally tipping and demountable, with volume $60 \mathrm{~m}^{3}$, is used to transport pre-ground and bulk wood material. The commonly used truck is the IVECO Stralis, on average 5 euros and 6 euros. Based on these, similar transport means reported in the Agri-footprint database (Transport, truck $>20$ t, EURO5, empty return/GLO Energy) with variable loading factors were selected to assess their impact, considering the load factor of each trip made. The load factor varied between $50-100 \%$ with an average of $73 \%$, primarily dependent on the particle size and shape of the residual material. Table 3 reports the average quantity of the residual biomass materials transported from different provinces to the power plant. In all, 12,514 road trips were analyzed for transporting varying amounts of biomass materials from other locations to 
the power plant. Based on the quantity of biomass transported and the distance covered, the $\mathrm{tkm}$ for each trip was calculated. In total, about 39 million $\mathrm{tkm}$ were calculated for 2017, considering that the annual average amount of biomass used by SMB corresponds to $138.5 \mathrm{tkm} /$ ton of biomass and $0.059 \mathrm{tkm} / \mathrm{MJ}$ EE (electrical energy).

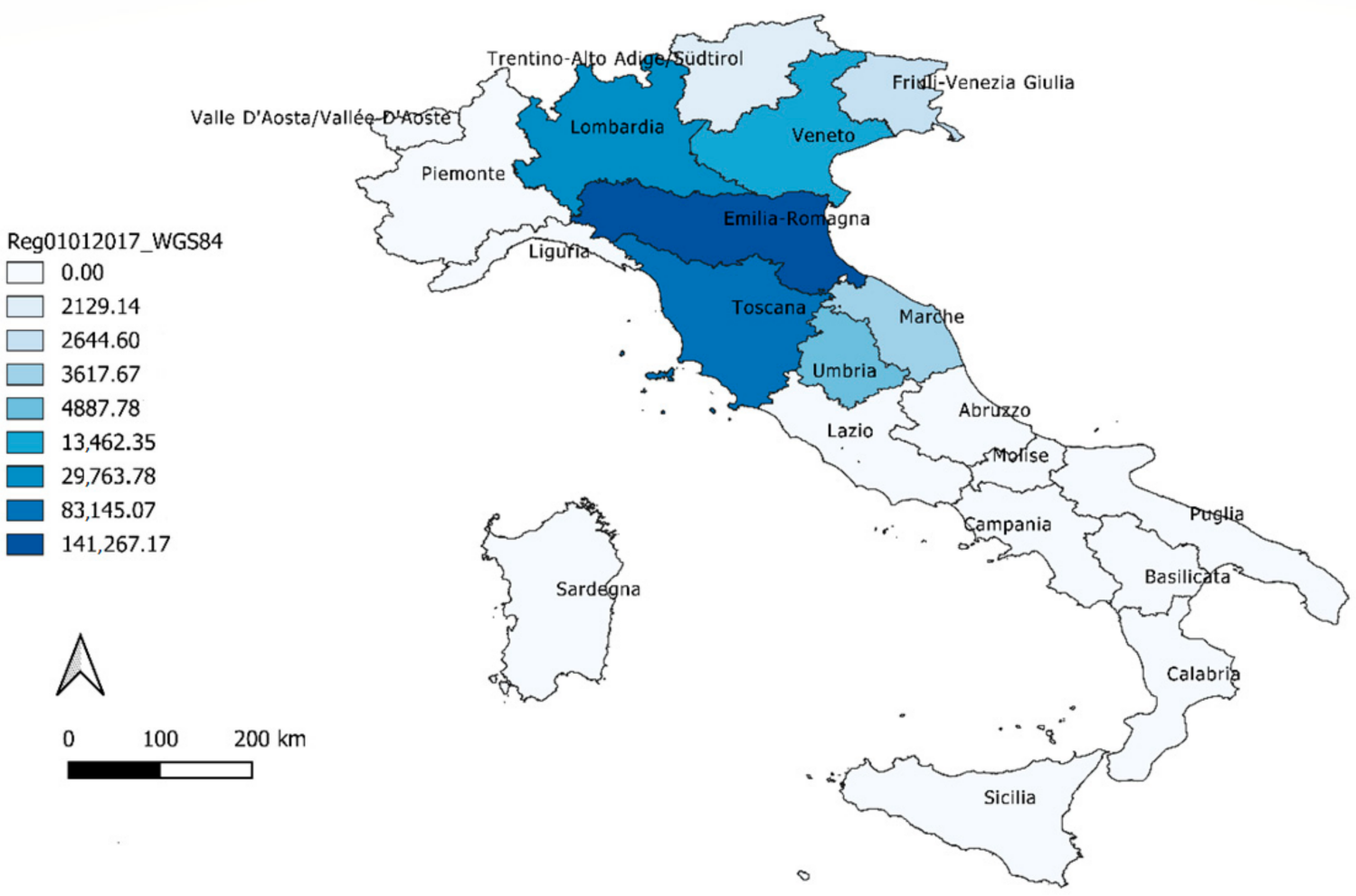

Figure 2. Regional distribution of raw biomass supply (tons) for SMB.

Table 3. The average quantity of biomass transported to the power plant from different locations.

\begin{tabular}{llll}
\hline Region & $\begin{array}{l}\text { Average Distance to the } \\
\text { Power Plant } \mathbf{( k m )}\end{array}$ & $\begin{array}{l}\text { Average Biomass } \\
\text { Transported per Trip (t) }\end{array}$ & Total Biomass Transported (t) \\
\hline Emilia-Romagna & 73 & 19.41 & 141,267 \\
Fruili-Venezia Giulia & 240 & 23.20 & 2644 \\
Lombardia & 172 & 22.91 & 29,736 \\
Marche & 228 & 27.62 & 3617 \\
Toscana & 212 & 26.86 & 83,145 \\
Trentino-Alto Adige & 250 & 29.57 & 2129 \\
Umbria & 283 & 27.61 & 4887 \\
Veneto & 116 & 23.13 & 13,462 \\
\hline
\end{tabular}

\subsubsection{Load Factor}

Based on the biomass typology, the load factor of the transported biomass was computed by expressing the quantity of material transported in terms of the maximum load transported by the truck. The $\mathrm{CO}_{2}$ emissions relating to the load factor were then estimated based on the reference for the lower limit from the SimaPro software shown in Table 3.

\subsubsection{Emissions for Transport}

Emissions from transport refer to the emission of $\mathrm{CO}_{2}$ per transport unit by the distance covered. The transport emissions were computed by comparing the actual load factor for each trip to the reference load factors in Table 4. Based on the quantity of material transported over the specified distance and using the reference emissions dependent on 
the different ranges reported in Table 4, the total emission for transportation was calculated using the equation:

Emissions $\left[\frac{g \mathrm{gO}_{2} \text { eq. }}{M J}\right]=\frac{\text { Specific } \mathrm{CO}_{2} \text { emission by } L F \times \text { Amount of biomass }[t] \times \text { distance }[\mathrm{km}]}{\left(\text { Amount of biomass }[t] \times\left(\frac{100-W C}{100}\right) \times L H V\left[\frac{\mathrm{MJ}}{\mathrm{kg} . \mathrm{dry}}\right] \times 1000\right)}$

where $L F=$ Load factor, $L H V=$ Lower Heating Value of biomass type.

Table 4. Estimated specific $\mathrm{CO}_{2}$ emissions by load factor $\mathrm{g} \mathrm{CO}_{2}$ eq./tkm (source SimaPro, EURO 5-6, Empty return).

\begin{tabular}{lllll}
\hline Biomass & Max. Load (t) & \multicolumn{2}{l}{ Lower Limits of Load Factor } \\
& & $\mathbf{8 1 - 1 0 0 \%}$ & $\mathbf{5 1 - 8 0 \%}$ & $<\mathbf{5 0}$ \\
\hline Wood Chips & 31 & 83.4 & 100.8 & 153 \\
Ground & 31 & 83.4 & 100.8 & 153 \\
MPS (Mixed ground) & 31 & 83.4 & 100.8 & 153 \\
MPS (Mixed pre-ground) & 20 & 83.4 & 100.8 & 153 \\
Pre-ground & 31 & 83.4 & 100.8 & 153 \\
Roots & 31 & 83.4 & 100.8 & 153 \\
Bulk & 20 & 83.4 & 100.8 & 153 \\
Stocked & 31 & 83.4 & 100.8 & 153 \\
\hline
\end{tabular}

\subsubsection{Processing and Storage of Biomass}

This phase consists of different operations, including unloading that affects all the products arriving at the plant, screening and grinding operations (when needed), and internal handling. The chipping of wood residues from forest management before transporting was included.

\subsubsection{Energy Conversion}

It concerns the process of energy conversion by combustion. This phase includes all the consumption of materials and energy necessary for the operation of the plant, including the fumes treatment system. In this phase, the reference flow is considered regarding electricity production. On the contrary, the heat is not recovered.

\subsubsection{Emissions for Processing and Energy Conversion Phases}

The processing phase encompasses the chipping operations, energy conversion, and ash treatment before disposal. Emissions for chipping were determined as the product of the amount of wood chips transport, and a reference characterization factor of $14.4 \mathrm{~g} \mathrm{CO}_{2}$ eq. $/ \mathrm{kg}$ wood chips produced was obtained from the Ecoinvent v.3.01 database (Wood chipping, mobile chipper, in forest, $\{$ RoW $\}$ | processing | Alloc Def, U) [50]. Wood biomass combustion releases flue gas containing substances such as $\mathrm{CO}, \mathrm{NO}_{\mathrm{x}}, \mathrm{SO}_{\mathrm{x}}, \mathrm{HCl}$, $\mathrm{CO}_{2}, \mathrm{H}_{2} \mathrm{O}, \mathrm{N}_{2}$, Polycyclic aromatic hydrocarbons, and unreacted surplus $\mathrm{O}_{2}$. These substances can be harmful, corrosive, and pollute the environment [51]. Thus, flue gas treatment through adsorption or chemical filtration is required before the fumes are released into the atmosphere. Emissions for other input materials were also calculated based on the quantity of materials per FU, shown in Table 5, by their corresponding characterization factors from the SimaPro software. The power plant's efficiency was about $25 \%$. 
Table 5. The life cycle inventory of the processing and energy conversion phases.

\begin{tabular}{|c|c|c|c|}
\hline Input & Use & Value & Unit \\
\hline Urea & $\begin{array}{l}\text { Removes dust and ammonia from waste gas } \\
\text { during scrubbing }\end{array}$ & $9.80 \times 10^{-4}$ & kg/MJ EE \\
\hline Sodium bicarbonate & Flue gas treatment & $2.35 \times 10^{-5}$ & $\mathrm{~kg} / \mathrm{MJ} \mathrm{EE}$ \\
\hline Hydrated lime & Acid gas treatment during wood combustion & $1.59 \times 10^{-4}$ & $\mathrm{~kg} / \mathrm{MJ} \mathrm{EE}$ \\
\hline Ferric chloride & Wastewater treatment & $1.09 \times 10^{-4}$ & kg/MJ EE \\
\hline Sodium hypochlorite & Auxiliary product & $1.77 \times 10^{-4}$ & $\mathrm{~kg} / \mathrm{MJ} \mathrm{EE}$ \\
\hline Sodium metabisulphite & Auxiliary product & $8.71 \times 10^{-6}$ & $\mathrm{~kg} / \mathrm{MJ} \mathrm{EE}$ \\
\hline Caustic soda & Flue gas treatment & $2.06 \times 10^{-6}$ & kg/MJ EE \\
\hline Sulfuric acid & Auxiliary product & $2.09 \times 10^{-4}$ & $\mathrm{~kg} / \mathrm{MJ} \mathrm{EE}$ \\
\hline Biomass & Input fuel & $4.26 \times 10^{-1}$ & $\mathrm{~kg} / \mathrm{MJ} \mathrm{EE}$ \\
\hline Energy import HV. & Processing & $9.63 \times 10^{-4}$ & $\mathrm{MJ} / \mathrm{MJ} \mathrm{EE}$ \\
\hline Energy import MV & Internal transportation of biomass & $1.01 \times 10^{-2}$ & MJ/MJ EE \\
\hline Energy import LV & Office use & $3.42 \times 10^{-5}$ & MJ/MJ EE \\
\hline Natural gas MP & Auxiliary fuel & $7.81 \times 10^{-3}$ & $\mathrm{MJ} / \mathrm{MJ} \mathrm{EE}$ \\
\hline Natural gas LP. & Auxiliary fuel & $9.75 \times 10^{-4}$ & $\mathrm{MJ} / \mathrm{MJ} \mathrm{EE}$ \\
\hline Diesel fuel & Internal biomass handling & $1.36 \times 10^{-2}$ & MJ/MJ EE \\
\hline Bottom ashes & Transport to disposal & $1.49 \times 10^{-3}$ & $\mathrm{tkm} / \mathrm{MJ} \mathrm{EE}$ \\
\hline Fly ashes & Transport to disposal & $8.40 \times 10^{-4}$ & $\mathrm{tkm} / \mathrm{MJ} \mathrm{EE}$ \\
\hline Bottom ashes & Landfill treatment & $9.91 \times 10^{-6}$ & t/MJ EE \\
\hline Fly ashes & Landfill treatment & $5.25 \times 10^{-6}$ & t/MJ EE \\
\hline
\end{tabular}

Note: $\mathrm{HT}=$ high tension, $\mathrm{MT}=$ medium tension, $\mathrm{LT}=$ low tension, $\mathrm{MP}=$ medium pressure, $\mathrm{LP}=$ low pressure, $\mathrm{EE}=$ electrical energy.

\subsubsection{Ash Disposal}

The company disposes of ash from biomass combustion by landfilling. The quantities of bottom and fly ash produced by SMB in 2017 were considered (bottom ash: 6399 t; fly ash: 3388 t). $90 \%$ of the landfill was carried out in Verona and 10\% in Pisa. The vehicle used to transport fly ash is a roll-off IVECO Stralis $\left(40 \mathrm{~m}^{3}\right)$ with an average load per journey of about $18 \mathrm{t}$. A tractor, such as those for transporting biomass, is used for the bottom ashes (euro 5) with an average load of $30 \mathrm{t} /$ trip and $40 \mathrm{~m}^{3}$ of volume.

\subsubsection{Data and Data Quality}

The analysis examined actual primary data referring to the production of SMB electricity in 2017 (to have a more mediated production value over time, especially for the inputs related to fumes treatment and processes in the plant). A total of 12,514 records corresponding to as many transports were analyzed for each record, different types of data were recorded such as quantity transported, supplier, province, municipality, and place of origin of the material, traceability data, description of the material (species, product family), humidity, data of means of transport and trailers. Other data, such as load factors, were calculated from the primary data collected. For the transport phase to the plant, all the transports carried out in 2017 were considered. All the data used relate to the specific company in question, and all the processes in the inventory represent national conditions or are calculated as a global average. In this study, all data referring to the material and energy flows used for the different phases was provided by the SMB company based on the administration of questionnaires and obtained from documentation relating to the traceability and quality systems already in place. The secondary data used include various processes selected from the Ecoinvent v.3.01 dataset [50] and generally refer to the production and transport of the inputs used. For uncertainty analysis, data variability in this study only relates to background processes such as inputs production in the databases selected as secondary data. 


\subsubsection{Assumptions and Allocation Procedures}

The system under analysis has only one function: producing renewable electricity. Therefore, no allocation procedures were carried out.

\subsubsection{Comparison of Results}

References to the European Commission's Directive 2018/2001 [52] were also considered to compare the impact of electricity generation from fossil sources (Fossil Fuel Comparator). Although the COM 2018 Directive [53] is not, in fact, a technical standard (such as the carbon footprint), it adopts calculation principles similar to the standards mentioned. The method to determine GHG emissions from the production and use of biofuels according to the EU sustainability criteria is based on the following procedure in the Directive (EU) 2018/2001 [52] and EU REDcert scheme [54]:

$$
\mathrm{E}=\mathrm{eec}+\mathrm{el}+\mathrm{ep}+\mathrm{etd}+\mathrm{eu}-\mathrm{esca}-\mathrm{eccs}-\mathrm{eccr}-\mathrm{eee}
$$

where $\mathrm{E}=$ total emissions from the use of the fuel; eec = emissions from the extraction or cultivation of raw materials; el = annualized emissions from carbon stock changes caused by land-use change; ep = emissions from processing; etd = emissions from transport and distribution; eu = emissions from the fuel in use; esca = emission saving from soil carbon accumulation via improved agricultural management; eccs = emission saving from carbon capture and geological storage; eccr = emission saving from carbon capture and replacement; and eee = emission saving from excess electricity from cogeneration.

GHG emissions from biomass fuels (E) are expressed in terms of grams of $\mathrm{CO}_{2}$ equivalent per $\mathrm{MJ}$ of biofuel ( $\mathrm{g} \mathrm{CO}_{2}$ eq./MJ). GHG from raw materials and intermediate products are represented in grams of $\mathrm{CO}_{2}$ equivalent per ton of dry feedstock and intermediate products ( $\mathrm{g} \mathrm{CO}_{2}$ eq./t dry).

Parameters such as el, esca, eccs, eccr, and eee are only applicable under specific assumptions and can be eliminated in the case of residual biofuel as irrelevant. Emissions arising from biofuels are also considered zero, as they are biogenic and therefore excluded in the calculations.

Thus, the final estimate of GHG emissions in this case study is based on the following formula:

$$
\mathrm{E}=\mathrm{ecc}+\mathrm{ep}+\mathrm{etd}
$$

However, in our study and in line with the EU Directive, ecc was considered zero as residual biomass material is used.

The calculated GHG emissions from our study are also compared to results from similar studies found in the literature.

\subsubsection{Greenhouse Gas Emissions Savings from Biofuel}

Finally, to better assess the extent of the impact, we calculated the GHG emissions savings based on the EU Directive formula:

$$
\text { Saving }=(\mathrm{Ef}-\mathrm{Eb}) / \mathrm{Ef}
$$

where $\mathrm{Ef}=$ total emissions for fossil fuels, a standard value of $183 \mathrm{~g} \mathrm{CO}_{2}$ eq. $/ \mathrm{MJ} \mathrm{EE}$ as fossil fuel comparator (FFC) [55], and Eb are the total emissions from the biofuel, this is currently one of the primary methods for assessing the sustainability of renewable energy production in Europe. The standard supply chain is energy production from the European energy mix, which is replaced by the supply chain from renewable sources, the SMB supply chain. We compared the $\mathrm{CO}_{2}$ emissions from reference supply chains for electricity production to evaluate the potential savings achievable by replacing the typical fossil supply chain and two popular short-rotation coppices supply chains (poplar and eucalyptus) [56]. 


\section{Results}

The summarized results for the quality parameters analyzed on the different biomass samples are reported in Table 5. Except for moisture content, all other results were expressed on a dry matter basis. The biomass typologies generally showed similar result trends for the different analyzed parameters. For most analyses, samples from conifer, orchard, hardwood, and precious woodchip recorded identical values. However, vine samples values were substantially higher for ash and nitrogen content and much lower for carbon and lower heating value (LHV). The vines' relatively higher mean value ash content could be due to residual soil particles from harvesting. The mean results and standard deviations of the biomass materials are detailed in Table 6.

Table 6. Results of characterization analysis performed on the biomass typologies.

\begin{tabular}{|c|c|c|c|c|c|c|}
\hline Parameter & Conifer & Orchard & Hardwood & $\begin{array}{l}\text { Mixed Orchard } \\
\text { and Vine }\end{array}$ & $\begin{array}{l}\text { Precious } \\
\text { Woodchip }\end{array}$ & Vine \\
\hline $\begin{array}{l}\text { Moisture content } \\
\text { (\% as received) }\end{array}$ & $39.22 \pm 8.85$ & $31.42 \pm 8.84$ & $39.16 \pm 8.85$ & $31.41 \pm 8.85$ & $33.22 \pm 8.85$ & $34.21 \pm 7.34$ \\
\hline LHV (MJ kg ${ }^{-1}$ d.m.) & $18.86 \pm 0.48$ & $17.95 \pm 0.81$ & $17.98 \pm 0.45$ & $16.65 \pm 1.36$ & $18.40 \pm 0.44$ & $15.35 \pm 1.91$ \\
\hline $\mathrm{LHV}\left(\mathrm{MJ} \mathrm{kg} \mathrm{kg}^{-1}\right.$ as received) & $11.47 \pm 2.00$ & $12.30 \pm 2.22$ & $10.97 \pm 1.87$ & $11.20 \pm 2.75$ & $12.89 \pm 1.35$ & $10.10 \pm 2.52$ \\
\hline Ash content (\% d.m.) & $2.83 \pm 2.28$ & $3.70 \pm 3.42$ & $4.54 \pm 1.91$ & $11.15 \pm 7.16$ & $3.09 \pm 1.79$ & $18.62 \pm 10.90$ \\
\hline Carbon content (\% d.m.) & $50.41 \pm 1.10$ & $48.00 \pm 2.74$ & $48.20 \pm 1.48$ & $43.54 \pm 4.03$ & $48.91 \pm 1.29$ & $39.08 \pm 5.31$ \\
\hline Hydrogen content (\% d.m.) & $5.81 \pm 0.20$ & $5.53 \pm 0.34$ & $5.67 \pm 0.20$ & $4.91 \pm 0.51$ & $5.61 \pm 0.20$ & $4.28 \pm 0.67$ \\
\hline Nitrogen content (\% d.m.) & $0.27 \pm 0.11$ & $0.36 \pm 0.15$ & $0.52 \pm 0.23$ & $0.59 \pm 0.15$ & $0.34 \pm 0.16$ & $0.82 \pm 0.15$ \\
\hline Oxygen content (\% d.m.) & $40.61 \pm 1.69$ & $42.41 \pm 1.62$ & $41.04 \pm 0.98$ & $39.76 \pm 4.32$ & $42.01 \pm 0.67$ & $37.11 \pm 7.01$ \\
\hline Chlorine content (\% d.m.) & $0.01 \pm 0.1$ & $0.01 \pm 0.1$ & $0.01 \pm 0.01$ & $0.02 \pm 0.04$ & $0.01 \pm 0.01$ & $0.02 \pm 0.07$ \\
\hline Sulfur content (\% d.m.) & $0.02 \pm 0.02$ & $0.01 \pm 0.02$ & $0.02 \pm 0.03$ & $0.01 \pm 0.02$ & $0.02 \pm 0.01$ & $0.01 \pm 0.02$ \\
\hline
\end{tabular}

In summary, as shown in Table 7, the average impact associated with $1 \mathrm{MJ}$ of SMB electricity production is $17.445 \mathrm{~g} \mathrm{CO}_{2}$ eq. The plant and transport of biomass are the primary impact contributors, followed by chipping in the field, while the disposal of the ashes affects relatively little. Figure 3 graphically represents the percentage contribution of the various phases considered to the previously calculated impact in the life cycle.

Table 7. The LCIA results of the SMB electricity production (all the values are expressed in $\mathrm{g} \mathrm{CO}_{2}$ eq./MJ EE).

\begin{tabular}{cc}
\hline Phase & Impact \\
\hline Biomass chipping & 4.299 \\
Transport of Biomass & 5.960 \\
Plant Materials Input & \\
Urea & 2.613 \\
Sodium bicarbonate & 0.063 \\
Hydrated lime & 0.133 \\
Ferric chloride & 0.119 \\
Sodium hypochlorite & 0.180 \\
Sodium metabisulphite & 0.015 \\
Caustic soda & 0.003 \\
Sulfuric acid & 0.026 \\
Plant Energy Input & \\
Energy import AT & 0.131 \\
Energy import MT & 1.422 \\
Energy import BT & 0.005 \\
Natural gas MP & 0.515 \\
Natural gas BP & 0.064 \\
Diesel fuel & 1.293 \\
Ash Disposal & \\
Bottom ash transport & 0.124 \\
Transport of light ashes & 0.070 \\
Ash dump & 0.409 \\
Total Average Impact & 17.445 \\
\hline
\end{tabular}




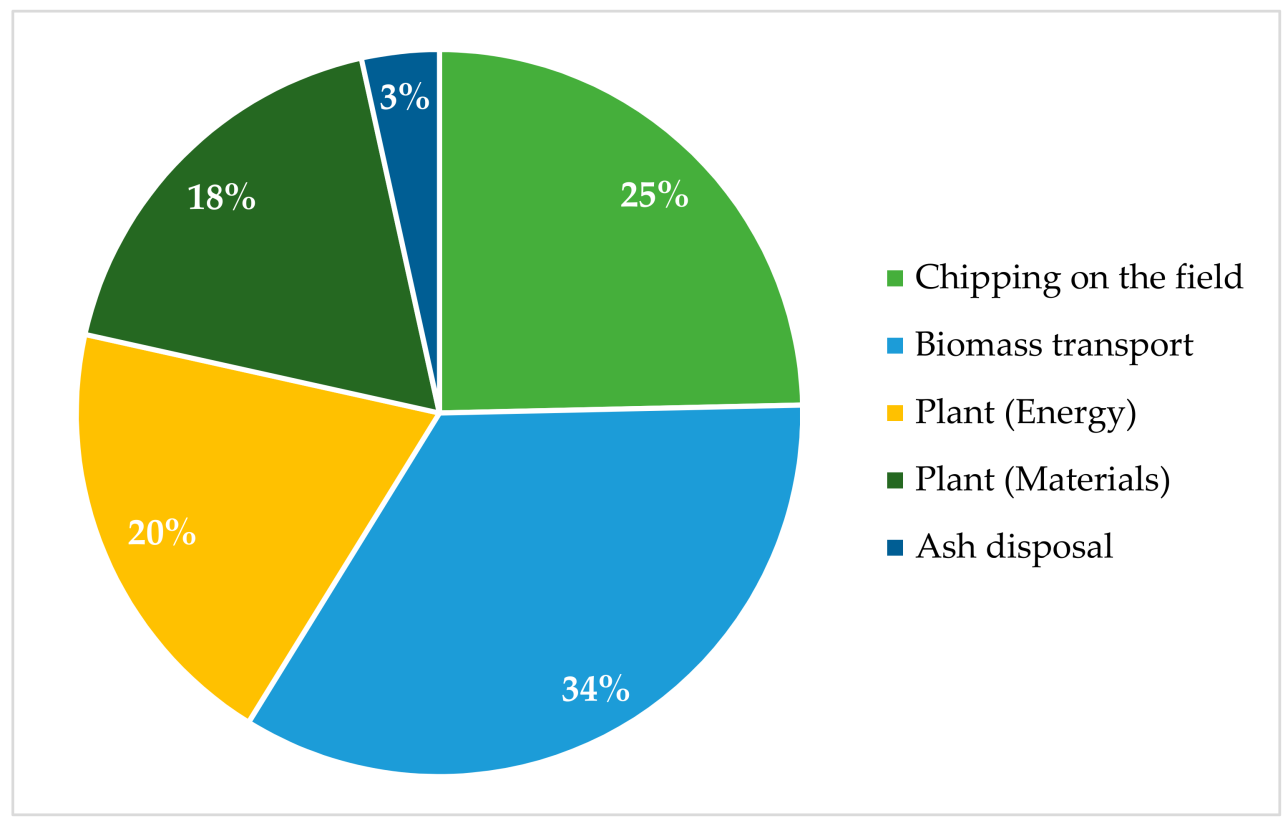

Figure 3. Percentage contribution of the various stages of the life cycle to the average SMB impact.

Figure 4 presents the average disaggregated GHG impacts associated with electricity generation at SMB. Energy impacts from wood chips from silviculture residues are almost twice the impacts of agricultural residue biomass. The lower global warming potential value of farm residues was mainly driven by the absence of the chipping operation and the relatively shorter distance over which the biomass is transported due to the proximity of the farm locations to the powerplant.

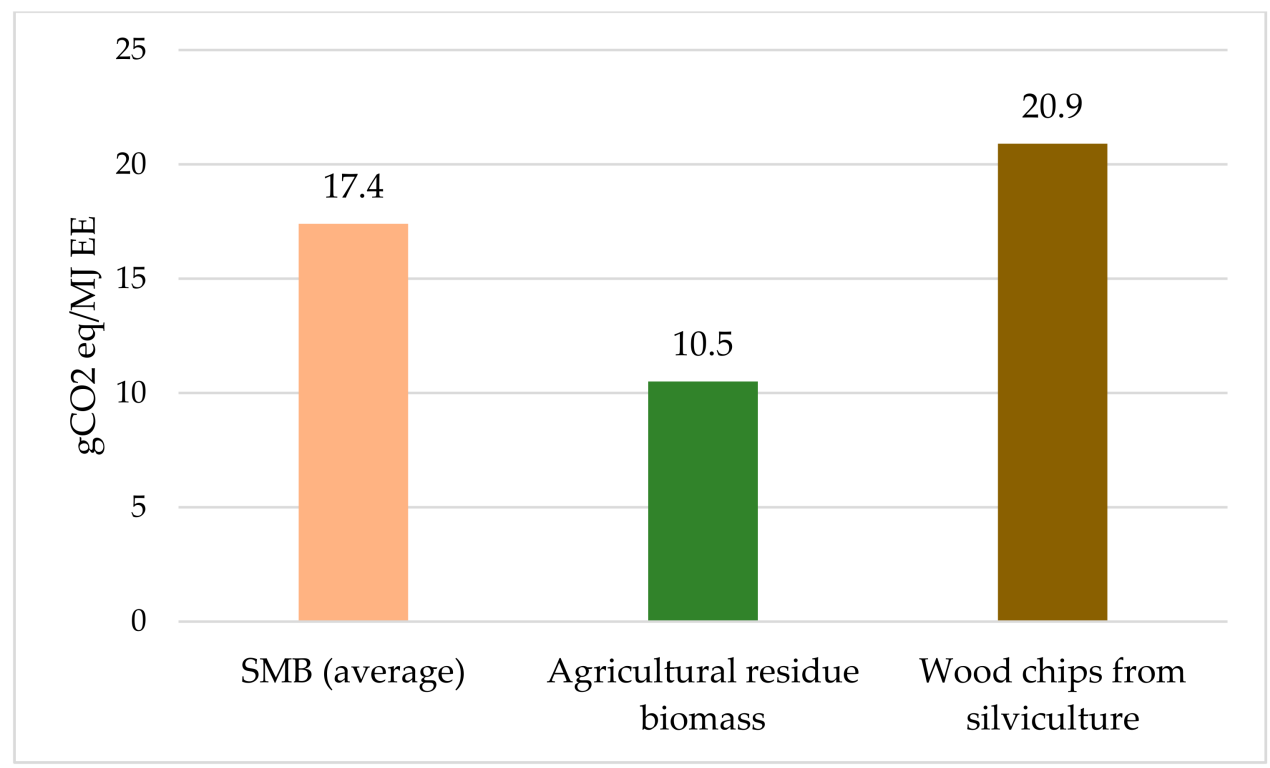

Figure 4. Energy impact from SMB biomass: average and specific biomass typology (expressed in $\mathrm{g} \mathrm{CO}_{2}$ eq./MJ EE).

\section{Discussion}

\subsection{Biomass Quality and Characterization}

Lignocellulosic biomass composition varies widely and often depends on its primary organic components (cellulose, hemicellulose, and lignin). The biomass source, species, climatic conditions, and other factors influence biomass composition [57]. Moisture content 
for the biomass typologies analyzed in this study ranged between 30 and $40 \%$, which conforms to the company's standards. The moisture content of biomass varies widely, ranging between 10 and 70\% [57,58]. The water content influences the combustion and flue gas volume produced per energy unit. The LHV of the fuel decreases with increasing moisture content. High moisture content can decrease the quality of biomass combustion by causing ignition issues and reducing the combustion temperature. The presence of water in biomass influences its behavior during pyrolysis and affects the physical properties and quality of the pyrolysis gases [58]. Moreover, a high moisture content results in increased fuel usage, generating large flue gas amounts incurring additional operational, environmental, and economic costs.

The mean ash content values of the samples were between the ranges of $2-5 \%$, except for vine. The composition of biomass ash is strongly dependent on the species and part of the biomass plant. The ash content of wood biomass is usually between 1 and $8 \%$ [57], while Vassilev et al. [59] reported a mean of $4.8 \%$ d.m. for wood residue ash content. The agricultural residue ash content varies between 1 and 19\% d.m. [57]. Sulfur and chlorine contents were below $0.1 \%$ for all the samples analyzed in this study (Table 6). Nitrogen contents for wood biomass were below $0.6 \%$, similar to a range of 0.1 to $0.5 \%$ on a dry basis reported by Vakkilainen [60]. The comparatively higher ash content (18\% d.m.) and nitrogen content $(0.82 \%$ d.m.) of vine residue are typical of biomass from agricultural residues, which can be attributed to the use of fertilizer and soil quality. Garcia et al. [61] reported an average ash content of $13.3 \% \mathrm{~d} . \mathrm{m}$. for grapevine residue. Other factors that can influence ash content include plant species or part of the plant, plant age, environmental conditions, growing processes, fertilizer and pesticide doses used, harvesting time, collection technique, transport, storage, pollution, processing, and contamination by dirt. Also, in terms of the plant part used, leaves have ash higher content than branches, bark, and roots $[59,62]$. Emissions from sulfur $\left(\mathrm{SO}_{2}\right)$, nitrogen $\left(\mathrm{NO}, \mathrm{NO}_{2}\right)$, particulate emissions are air pollutants from biomass combustion that have significant environmental and health implications. Chlorine can also be either found in the dust as solid $\mathrm{NaCl}$ and $\mathrm{KCl}$ or can exit in flue gases as $\mathrm{HCl}$ and $\mathrm{Cl}_{2}$ after combustion [60]. Residual biomass with low ash content is ideal since ash management in removal, treatment, and disposal in landfill areas increases economic, environmental, and social costs for energy plants.

Biofuels consist primarily of carbon, hydrogen, and oxygen (CHO). Most of the carbon is converted in the combustion process to carbon dioxide $\left(\mathrm{CO}_{2}\right)$ and most of the hydrogen to water vapor $\left(\mathrm{H}_{2} \mathrm{O}\right)$. Generally, biomass has less carbon, more oxygen, and higher hydrogen content than coal. Apart from biomass from the vineyard (39\% d.m.), the mean carbon content ranged between 43 and 51\% d.m. Hydrogen content for all samples ranged between 4 and $6 \%$ d.m., while oxygen content was in the range of $40-43 \%$ d.m., except for vine ( $37 \%$ d.m.), Table 6. Lignocellulosic biomass composition regarding $\mathrm{CHO}$ is similar. Typical (dry) weight percentages for $\mathrm{C}, \mathrm{H}$, and $\mathrm{O}$ are 30 to $60 \%, 5$ to $6 \%$, and 30 to $45 \%$, respectively [58]. Lower heating values (LHV) ranging between 15 and $19 \mathrm{MJ} \mathrm{kg}^{-1} \mathrm{~d} . \mathrm{m}$. for the samples analyzed in this study fall within the typical energy contents of different types of biomass [62]. LHV is highly influenced by the water content of the biomass and is an important parameter that describes the suitability and value of biomass use as biofuel. High carbon and hydrogen content and low oxygen content increase the biomass's heating value [58].

\subsection{Carbon Footprint of Biomass Power Plant}

The results from the study show that GHG emissions associated with electricity generation from agricultural and silviculture residues are comparably lower to other energy sources, considering plant efficiency of about $25 \%$. Our findings on emissions from electricity production from residual woody and agricultural biomass for electricity generation complement other studies showing bioenergy's environmental sustainability (Table 8$)$. The impact related to the plant $(38 \%)$ is the highest, determined to a similar extent using material inputs (especially urea) and energy (electricity from the grid and diesel). The contribution of biomass transport is very similar (34\%), followed by chipping in the 
field $(25 \%)$. The disposal of ashes is less significant (3\%). It is also possible to differentiate the impact of SMB energy production from further details by considering the different biomasses used. We compared the average SMB energy impact (all kinds of biomass), SMB energy impact only from residual agricultural biomass, and SMB energy impact only from wood chips from forest maintenance (Figure 5). The energy production chain from residual agricultural biomass is less impactful, about half than wood chips from forest maintenance. The relative proximity of the orchards to the power plant in the Emilia-Romagna region explains the lower impacts associated with residual agricultural biomass. In the case of wood chips from forest maintenance, this difference is due to the need to chip in the field and the higher average distance. Transportation of biomass materials, especially the type of transport means and distance, has been shown to significantly impact the overall GHG emissions from biomass electricity generation [14,63-66]. Thus, the sourcing of biomass raw material warrants careful consideration during power plant construction.

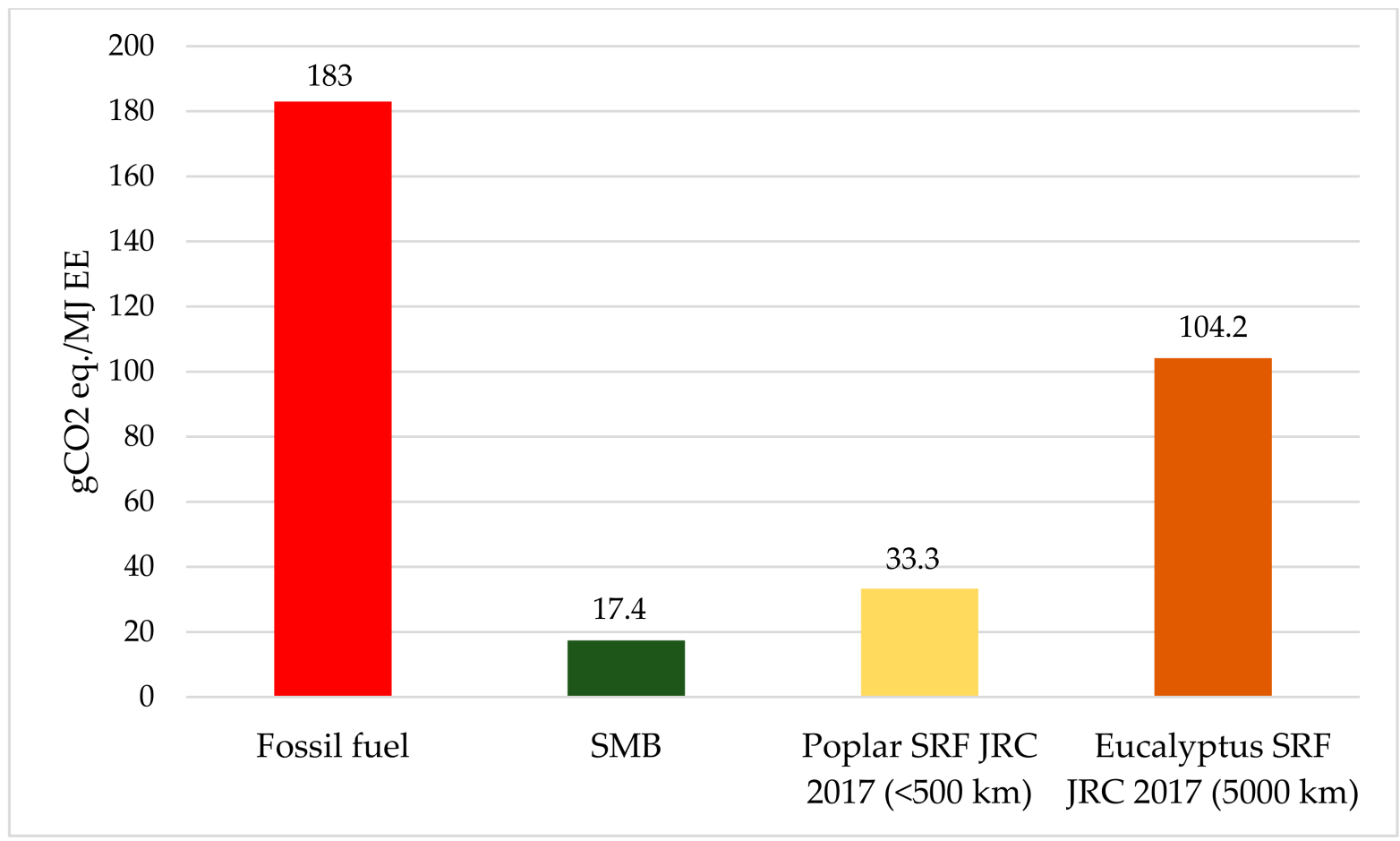

Figure 5. Comparison between the average impact of biomass energy production from SMB, the fossil reference FFC, and two chains from SRF (JRC, 2015). Data expressed in $\mathrm{g} \mathrm{CO}_{2}$ eq. / MJ EE.

Several factors need to be considered in assessing the environmental sustainability of producing electricity from biomass. The biomass typology, biomass cultivation, conversion technology, and distance for transported biomass significantly affect emissions. Tables 8 and 9 summarize impact assessment studies conducted on GHG emissions related to electricity generation from different biomass typologies expressed in $\mathrm{g} \mathrm{CO}_{2}$ eq. $/ \mathrm{kWh}$. Results vary greatly depending on the phases considered in the system boundary. Generally, high emissions are associated with biomass cultivation due to fertilizer and pesticide use, power plant construction, and conversion technology used. The result from our study, $63 \mathrm{~g} \mathrm{CO}_{2} \mathrm{eq}$./ $\mathrm{kWhe}$, was relatively lower compared to previous studies reported in Table 8. Additionally, in this study, the net biogenic $\mathrm{CO}_{2}$ emissions released from the combustion of the biomass material were considered to be zero based on the general assumption in many bioenergy LCAs that $\mathrm{CO}_{2}$ will be removed from the atmosphere by biomass regrowth $[67,68]$.

Biomass is converted to electricity via three main technology categories: pyrolysis, gasification, and direct combustion. Pyrolysis involves the heat destruction of biomass under anaerobic conditions, without the addition of steam or air to produce gases and 
condensable vapors [69]. Gasification involves partial oxidation of biomass under steamcontrolled oxygen to produce combustible gases with a high calorific value. Product gases are fed into a combined cycle gas turbine, while direct combustion is the complete oxidation of biomass in excess air to produce carbon dioxide and water. Hot flue gases heat process water to steam, which propels a turbine, usually via a Rankine cycle [70]. Although gasification and pyrolysis appear more popular than combustion due to their higher efficiency, they require more process control and investment [71]. Loucao et al. [72] and Briones-Hidrovo et al. [73] reported low emissions values for IGCC (integrated gasification combined cycle) in comparison with combustion-Rankine cycles systems. However, the boiler technology of the SMB power plant is based on an air-cooled grate and a steam generator. The combustion system is equipped with a superheated steam generator, a steam turbine, and a connected electric generator and systems to reduce atmospheric emissions in line with the most advanced technology available (BAT), which accounts for the overall low GHG emissions.

Table 8. A literature review on GHG emissions for electricity generation from biomass materials.

\begin{tabular}{|c|c|c|c|c|c|}
\hline Author (s) & Year & Location & Biomass Type & Conversion Technology & $\begin{array}{l}\text { GHG Emission } \\
\mathrm{g} \mathrm{CO}_{2} \text { eq./kWhe }\end{array}$ \\
\hline Rafaschieri et al. [74] & 1999 & Italy & Poplar & Pressurized fluid bed gasifier & 110 \\
\hline Carpentieri et al. [75] & 2005 & Italy & Poplar & Integrated gasification combined cycle & $178 *$ \\
\hline Puy et al. [76] & 2010 & Spain & $\begin{array}{l}\text { Wood waste } \\
\text { Forest residue }\end{array}$ & $\begin{array}{l}\text { Gasification for electricity and thermal } \\
\text { production }\end{array}$ & $\begin{array}{l}568 \\
871\end{array}$ \\
\hline Butnar et al. [64] & 2010 & Spain & $\begin{array}{l}\text { Poplar } \\
\text { Ethiopian Mustard }\end{array}$ & Direct combustion & $\begin{array}{l}100-150 \\
180-300\end{array}$ \\
\hline Siegl et al. [77] & 2011 & Austria & Wood chips & $\begin{array}{l}\text { Direct combustion } \\
\text { Gasification }\end{array}$ & $\begin{array}{l}80 \\
90\end{array}$ \\
\hline Wang et al. [78] & 2012 & China & Woody material & Gasification & 144 \\
\hline Roder et al. [79] & 2015 & UK & $\begin{array}{l}\text { Forest residues } \\
\text { Sawmill residues }\end{array}$ & Direct combustion & $\begin{array}{l}132 \\
140\end{array}$ \\
\hline Paengjuntuek et al. [80] & 2015 & Thailand & $\begin{array}{l}\text { Rice straw } \\
\text { Pine }\end{array}$ & Integrated biomass gasification fuel cell & $\begin{array}{l}864 \\
380 * *\end{array}$ \\
\hline Nian [81] & 2016 & Singapore & $\begin{array}{l}\text { Poplar } \\
\text { Willow }\end{array}$ & Direct combustion & $\begin{array}{l}270 \\
250\end{array}$ \\
\hline Chary et al. [65] & 2018 & France & $\begin{array}{l}\text { Energy cane } \\
\text { Wood pellet }\end{array}$ & Cogeneration plant-multifueled boiler & $\begin{array}{l}234 \\
237\end{array}$ \\
\hline da Costa et al. [82] & 2018 & Portugal & Forest residues & Biomass gasification fuel cell system & $98.30-163.1$ \\
\hline Yang et al. [83] & 2018 & China & Rice husks and straw & Biomass gasification combined cycle & 493 \\
\hline Beagle and Belmont [14] & 2019 & EU. & $\begin{array}{l}\text { Chips } \\
\text { Pellets }\end{array}$ & Combustion with a steam turbine & $\begin{array}{l}430 \\
400\end{array}$ \\
\hline Loucao et al. [72] & 2019 & Portugal & Forest residue & $\begin{array}{l}\text { Integrated gasification combined cycle } \\
\text { Rankine cycle }\end{array}$ & $\begin{array}{l}2757 \\
3315\end{array}$ \\
\hline Siregar et al. [84] & 2020 & Indonesia & Oil palm residue & Gasifier & 152 \\
\hline Zang et al. [85] & 2020 & $\begin{array}{l}\text { Not } \\
\text { specified }\end{array}$ & Pinewood & Integrated gasification combined cycles & $203-239$ \\
\hline Briones-Hidrovo et al. [73] & 2021 & Portugal & Forest residues & $\begin{array}{l}\text { Integrated gasification combined cycles } \\
\text { Combustion Rankine Cycle }\end{array}$ & $\begin{array}{l}78 \\
109\end{array}$ \\
\hline Present study & 2021 & Italy & $\begin{array}{l}\text { Forest residues } \\
\text { Agricultural residues }\end{array}$ & Direct combustion-Boilers & 63 \\
\hline
\end{tabular}

${ }^{*}$ Biogenic emission of $\mathrm{CO}_{2}$ released from gasification or combustion included. ${ }^{* *}$ Corrected biogenic $\mathrm{CO}_{2}$ emissions. 
Table 9. The considered processes within the system boundaries in the analyzed studies.

\begin{tabular}{llllllll}
\hline Author (s) & $\begin{array}{l}\text { Biomass } \\
\text { Production }\end{array}$ & Chipping & Pelletize & Transport & $\begin{array}{l}\text { Plant } \\
\text { Construction }\end{array}$ & $\begin{array}{l}\text { Electricity } \\
\text { Conversion }\end{array}$ & $\begin{array}{l}\text { Ash } \\
\text { Disposal }\end{array}$ \\
\hline Rafaschieri et al. [74] & $\mathrm{x}$ & - & - & $\mathrm{x}$ & - & $\mathrm{x}$ & - \\
Carpentieri et al. [75] & $\mathrm{x}$ & - & - & $\mathrm{x}$ & $\mathrm{x}$ & $\mathrm{x}$ & - \\
Puy et al. [76] & - & $\mathrm{x}$ & - & $\mathrm{x}$ & - & $\mathrm{x}$ & - \\
Butnar et al. [64] & $\mathrm{x}$ & $\mathrm{x}$ & - & $\mathrm{x}$ & - & $\mathrm{x}$ & $\mathrm{x}$ \\
Siegl et al. [77] & $\mathrm{x}$ & $\mathrm{x}$ & - & $\mathrm{x}$ & $\mathrm{x}$ & $\mathrm{x}$ & $\mathrm{x}$ \\
Wang et al. [78] & $\mathrm{x}$ & - & - & $\mathrm{x}$ & $\mathrm{x}$ & $\mathrm{x}$ & - \\
Roder et al. [79] & $\mathrm{x}$ & $\mathrm{x}$ & $\mathrm{x}$ & $\mathrm{x}$ & - & $\mathrm{x}$ & - \\
Paengjuntuek et al. [80] & - & - & - & $\mathrm{x}$ & $\mathrm{x}$ & \\
Nian [81] & $\mathrm{x}$ & - & $\mathrm{x}$ & $\mathrm{x}$ & - & $\mathrm{x}$ & \\
Chary et al. [65] & $\mathrm{x}$ & - & $\mathrm{x}$ & $\mathrm{x}$ & - & $\mathrm{x}$ & \\
da Costa et al. [82] & $\mathrm{x}$ & $\mathrm{x}$ & - & $\mathrm{x}$ & - & $\mathrm{x}$ & - \\
Yang et al. [83] & $\mathrm{x}$ & - & - & $\mathrm{x}$ & $\mathrm{x}$ & $\mathrm{x}$ & $\mathrm{x}$ \\
Beagle and Belmont [14] & - & $\mathrm{x}$ & $\mathrm{x}$ & $\mathrm{x}$ & - & $\mathrm{x}$ & \\
Loucao et al. [72] & $\mathrm{x}$ & $\mathrm{x}$ & - & $\mathrm{x}$ & - & $\mathrm{x}$ & - \\
Siregar et al. [84] & $\mathrm{x}$ & - & - & $\mathrm{x}$ & - & $\mathrm{x}$ & \\
Zang et al. [85] & $\mathrm{x}$ & - & - & $\mathrm{x}$ & $\mathrm{x}$ & $\mathrm{x}$ & $\mathrm{x}$ \\
Briones-Hidrovo et al. [73] & $\mathrm{x}$ & $\mathrm{x}$ & - & - & $\mathrm{x}$ & $\mathrm{x}$ \\
Present study & - & $\mathrm{x}$ & - & $\mathrm{x}$ & - & $\mathrm{x}$ \\
\hline
\end{tabular}

\subsection{GHG Emissions Savings}

The emission savings obtainable by replacing these supply chain with the SMB renewable supply chain is shown in Figure 5. The savings on the fossil supply chain with the SMB renewable supply chain is $90.5 \%$. Considering the SMB electricity production for the year 2017, this saving, in absolute terms, is equal to 106,594 tons of $\mathrm{CO}_{2}$ eq. The emissions savings in this study is comparable to varying range levels of $25-88 \%$, with a mean of $71 \%$ reported in the reviewed studies. The phases considered within the system boundary, especially cultivation, energy conversion, and inclusion of biogenic $\mathrm{CO}_{2}$, account for the differences.

\section{Conclusions}

With global energy trends moving towards phasing fossil fuels to renewables, GHG emissions from electricity generation from biomass supply chains are vital to their sustainability and promotion. Biomass quality significantly affects various technical, economic, and environmental aspects for generating electricity. We assessed the chemical and ultimate analysis for the different biomass typologies used by the SMB power plant. All the residues' samples showed good features, signifying their suitability for biofuel use. However, residue from vine recorded high ash content $(18 \%)$, possible for an agricultural residue. The LHV of the biomass analyzed on a dry basis fell in the expected range of $15-21 \mathrm{MJ} \mathrm{kg}^{-1}$ for plant species.

This study presents a partial life cycle assessment of the supply chain emissions related to generating electricity from residual biomass from orchards and forest management, excluding impacts from plant construction and dismantling. Variability in data was mainly associated with the biomass type, transportation distance of biomass. Emissions from electricity generated from the power plant are $17.4 \mathrm{~g} \mathrm{CO}_{2}$ eq. $/ \mathrm{MJ} \mathrm{EE}$. The savings obtainable by replacing the reference fossil supply chain (FFC) with the SMB renewable supply chain is $90.5 \%$. The SMB supply chain, characterized by residual biomass, is significantly more sustainable than the supply chains based on dedicated forest biomass due to high impacts from biomass cultivation and transportation of biomass. It is worthy to note that these results are based on data related to the system boundary considered in the study (described under Section 2.2). Local sourcing biomass materials with an efficient logistics system does not only present environmental benefits but significant economic advantages regarding various logistics aspects of biomass transport and energy distribution. As policymakers and interested stakeholders reduce GHG emissions related to the electricity sector by promoting 
renewable biomass energy, an ideal situation worthy of consideration would be sourcing biomass materials relatively close to the power plant, as shown in this study.

The Life Cycle Assessment methodology, although very useful, is also characterized by some limitations. Although the ISO standard gives a consensus definition for LCA and provides a general framework for conducting an assessment, much interpretation is dependent on the expert conducting the evaluation, which may lead to high variation among results for even the same product. The wide variation is evident in emission results for biomass materials from previous works, even for the same system boundary considered. Other limitations include time and resource constraints in gathering inventory data, missing impact data and models for LCIA, data uncertainty challenges, environmental burden allocation across coproducts, and assigning credit for avoided burden. Despite these limitations, the LCA offers a robust environmental tool in the movement toward sustainability.

Author Contributions: Conceptualization, G.T. and D.D.; methodology, D.D. and A.I.; software, A.I.; validation, A.I. and K.A.B.-Y.; formal analysis, A.I., K.A.B.-Y. and T.G.; investigation, A.I. and G.T.; resources, G.T.; data curation, D.D. and A.I.; writing-original draft preparation, D.D., A.I., and T.G.; writing—review and editing, K.A.B.-Y. and G.T.; visualization, A.I.; supervision, G.T. and D.D.; project administration, G.T.; funding acquisition, G.T. All authors have read and agreed to the published version of the manuscript.

Funding: This research was funded by San Marco Bioenergie SpA, research contract "Valorizzazione energetica di biomasse residuali: stato dell'arte, screening qualitativo e sostenibilità dell'approvvigionamento". Project Leader Giuseppe Toscano.

Institutional Review Board Statement: Not applicable.

Informed Consent Statement: Not applicable.

Data Availability Statement: The data presented in this study are available on request from the corresponding author.

Conflicts of Interest: The authors declare no conflict of interest. The funders had no role in the design of the study; in the analyses and interpretation of data; in the writing of the manuscript, or in the decision to publish the results.

\section{References}

1. Masson-Delmotte, V.; Zhai, P.; Pirani, A.; Connors, S.L.; Péan, C.; Berger, S.; Caud, N.; Chen, Y.; Goldfarb, L.; Gomis, M.I.; et al. (Eds.) Full Report Chapter 3: Human Influence on the Climate System. In Climate Change 2021: The Physical Science Basis. Contribution of Working Group I to the Sixth Assessment Report of the Intergovernmental Panel on Climate Change; Cambridge University Press: Cambridge, UK, 2021.

2. $\quad$ Masson-Delmotte, V.; Zhai, P.; Pirani, A.; Connors, S.L.; Péan, C.; Berger, S.; Caud, N.; Chen, Y.; Goldfarb, L.; Gomis, M.I.; et al. (Eds.) Summary for Policymakers. In Climate Change 2021: The Physical Science Basis. Contribution of Working Group I to the Sixth Assessment Report of the Intergovernmental Panel on Climate Change; Cambridge University Press: Cambridge, UK, 2021 ; Volume 18.

3. Janik, A.; Ryszko, A.; Szafraniec, M. Greenhouse gases and circular economy issues in sustainability reports from the energy sector in the European union. Energies 2020, 13, 5993. [CrossRef]

4. IEA. Global Energy Review 2021: Assessing the Effects of Economic Recoveries on Global Energy Demand and $\mathrm{CO}_{2}$ Emissions in 2021; IEA: Paris, France, 2021.

5. Anderson, J.; Fergusson, M.; Valsecchi, C. An overview of global greenhouse gas emissions and emissions reduction scenarios for the future. Eur. Parliam. 2007, 2, 11.

6. Enerdata. Global Energy Statistical Yearbook 2021; Enerdata: Grenoble, France, 2021.

7. Delbeke, J.; Runge-Metzger, A.; Slingenberg, Y.; Werksman, J. The paris agreement. In Towards a Climate-Neutral Europe; Curbing Trend; Routledge: London, UK, 2019; pp. 24-45. [CrossRef]

8. European Commission. A Clean Planet for All. A European Long-Term Strategic Vision for a Prosperous, Modern, Competitive and Climate Neutral Economy; Com (2018) 773; European Commission: Brussels, Belgium, 2018; p. 114.

9. Schöpe, M. Renewable energy directive. Eur. Wind Energy Conf. Exhib. 2008, 1, 32-38.

10. Rotatori, M.; Di Franco, S.; Mosca, S.; Salvatori, R. Study on the Environmental Effects Related to the Use of Solid Biomass for the Production of Electricity; CNR-IIA; Institute on Air Pollution: Monterotondo, Italy, 2019. Available online: https://www. centralemercure.it/wp-content/uploads/2020/06/Studio-sugli-effetti-ambientali-uso-biomassa-EBS-2019.pdf (accessed on 28 October 2021).

11. IEA. World Energy Outlook 2019 Executive Summary. In World Energy Outlook 2019; IEA: Paris, France, 2019. 
12. Kimming, M.; Sundberg, C.; Nordberg, Å.; Baky, A.; Bernesson, S.; Norén, O.; Hansson, P.A. Biomass from agriculture in small-scale combined heat and power plants-A comparative life cycle assessment. Biomass Bioenergy 2011, 35, 1572-1581. [CrossRef]

13. Mann, M.K.; Spath, P.L. Life Cycle Assessment of a Biomass Gasification Combined-Cycle Power System; National Renewable Energy Lab.: Golden, CO, USA, 1997. [CrossRef]

14. Beagle, E.; Belmont, E. Comparative life cycle assessment of biomass utilization for electricity generation in the European Union and the United States. Energy Policy 2019, 128, 267-275. [CrossRef]

15. Uusitalo, V.; Havukainen, J.; Manninen, K.; Höhn, J.; Lehtonen, E.; Rasi, S.; Soukka, R.; Horttanainen, M. Carbon footprint of selected biomass to biogas production chains and GHG reduction potential in transportation use. Renew. Energy 2014, 66, 90-98. [CrossRef]

16. Lam, H.L.; Varbanov, P.; Klemeš, J. Minimising carbon footprint of regional biomass supply chains. Resour. Conserv. Recycl. 2010, 54, 303-309. [CrossRef]

17. IEA. Electricity Generated from Biofuels and Waste by Sources-Italy. 2021. Available online: www.iea.org/data-and-statistics/ data-product/renewables-information (accessed on 2 September 2021).

18. Anukam, A.; Mamphweli, S.; Reddy, P.; Meyer, E.; Okoh, O. Pre-processing of sugarcane bagasse for gasification in a downdraft biomass gasifier system: A comprehensive review. Renew. Sustain. Energy Rev. 2016, 66, 775-801. [CrossRef]

19. Toscano, G.; Leoni, E.; Feliciangeli, G.; Duca, D.; Mancini, M. Application of ISO standards on sampling and effects on the quality assessment of solid biofuel employed in a real power plant. Fuel 2020, 278, 118142. [CrossRef]

20. Deboni, T.L.; Simioni, F.J.; Brand, M.A.; Lopes, G.P. Evolution of the quality of forest biomass for energy generation in a cogeneration plant. Renew. Energy 2019, 135, 1291-1302. [CrossRef]

21. Fournel, S.; Palacios, J.H.; Morissette, R.; Villeneuve, J.; Godbout, S.; Heitz, M.; Savoie, P. Influence of biomass properties on technical and environmental performance of a multi-fuel boiler during on-farm combustion of energy crops. Appl. Energy 2015, 141, 247-259. [CrossRef]

22. Toscano, G.; Riva, G.; Foppa Pedretti, E.; Corinaldesi, F.; Mengarelli, C.; Duca, D. Investigation on wood pellet quality and relationship between ash content and the most important chemical elements. Biomass Bioenergy 2013, 56, 317-322. [CrossRef]

23. Fauzi, R.T.; Lavoie, P.; Sorelli, L.; Heidari, M.D.; Amor, B. Exploring the current challenges and opportunities of Life Cycle Sustainability Assessment. Sustainability 2019, 11, 636. [CrossRef]

24. Saeed, A.; Noreen, U.; Azam, A.; Tahir, M.S. Does csr governance improve social sustainability and reduce the carbon footprint: International evidence from the energy sector. Sustainability 2021, 13, 3596. [CrossRef]

25. Koornneef, J.; van Keulen, T.; Faaij, A.; Turkenburg, W. Life cycle assessment of a pulverized coal power plant with postcombustion capture, transport and storage of $\mathrm{CO}_{2}$. Int. J. Greenh. Gas Control 2008, 2, 448-467. [CrossRef]

26. Kucukvar, M.; Tatari, O. A comprehensive life cycle analysis of cofiring algae in a coal power plant as a solution for achieving sustainable energy. Energy 2011, 36, 6352-6357. [CrossRef]

27. Han, X.; Chen, N.; Yan, J.; Liu, J.; Liu, M.; Karellas, S. Thermodynamic analysis and life cycle assessment of supercritical pulverized coal-fired power plant integrated with No.0 feedwater pre-heater under partial loads. J. Clean. Prod. 2019, 233, 1106-1122. [CrossRef]

28. Rasheed, R.; Javed, H.; Rizwan, A.; Sharif, F.; Yasar, A.; Tabinda, A.B.; Ahmad, S.R.; Wang, Y.; Su, Y. Life cycle assessment of a cleaner supercritical coal-fired power plant. J. Clean. Prod. 2021, 279, 123869. [CrossRef]

29. Piemonte, V.; de Falco, M.; Tarquini, P.; Giaconia, A. Life Cycle Assessment of a high temperature molten salt concentrated solar power plant. Sol. Energy 2011, 85, 1101-1108. [CrossRef]

30. Whitaker, M.B.; Heath, G.A.; Burkhardt, J.J.; Turchi, C.S. Life cycle assessment of a power tower concentrating solar plant and the impacts of key design alternatives. Environ. Sci. Technol. 2013, 47, 5896-5903. [CrossRef]

31. Hanafi, J.; Riman, A. Life cycle assessment of a mini hydro power plant in Indonesia: A case study in Karai River. Procedia CIRP 2015, 29, 444-449. [CrossRef]

32. Scherer, L.; Pfister, S. Hydropower's biogenic carbon footprint. PLoS ONE 2016, 11, e0161947. [CrossRef] [PubMed]

33. Pfister, S.; Nauser, I. Greenhouse Gas Emissions of Selected Hydropower Reservoirs; ETH Zurich: Zurich, Switzerland, 2020.

34. Tomasini-Montenegro, C.; Santoyo-Castelazo, E.; Gujba, H.; Romero, R.J.; Santoyo, E. Life cycle assessment of geothermal power generation technologies: An updated review. Appl. Therm. Eng. 2017, 114, 1119-1136. [CrossRef]

35. Frick, S.; Kaltschmitt, M.; Schröder, G. Life cycle assessment of geothermal binary power plants using enhanced low-temperature reservoirs. Energy 2010, 35, 2281-2294. [CrossRef]

36. Buonocore, E.; Vanoli, L.; Carotenuto, A.; Ulgiati, S. Integrating life cycle assessment and emergy synthesis for the evaluation of a dry steam geothermal power plant in Italy. Energy 2015, 86, 476-487. [CrossRef]

37. Karlsdottir, M.R.; Heinonen, J.; Palsson, H.; Palsson, O.P. Life cycle assessment of a geothermal combined heat and power plant based on high temperature utilization. Geothermics 2020, 84, 101727. [CrossRef]

38. Singh, B.; Strømman, A.H.; Hertwich, E. Life cycle assessment of natural gas combined cycle power plant with post-combustion carbon capture, transport and storage. Int. J. Greenh. Gas Control 2011, 5, 457-466. [CrossRef]

39. Medeiros, D.L.; Sales, E.A.; Kiperstok, A. Energy production from microalgae biomass: Carbon footprint and energy balance. J. Clean. Prod. 2015, 96, 493-500. [CrossRef]

40. ISO 14780:2017; Solid Biofuels—Sample Preparation. ISO: Geneva, Switzerland, 2017.

41. ISO 18134-1:2015; Solid Biofuels-Determination of Moisture Content-Oven Dry Method. ISO: Geneva, Switzerland, 2015.

42. BS EN ISO 18125:2017; Solid Biofuels-Determination of Calorific Value. BSI Standards Publication: London, UK, 2017.

43. ISO 18122:2015; Solid Biofuels-Determination of Ash Content. ISO: Geneva, Switzerland, 2015. 
44. ISO 16948:2015; Solid Biofuels-Determination of Total Content of Carbon, Hydrogen and Nitrogen. BSI Standards Publication: London, UK, 2015.

45. ISO 16994:2016; Solid Biofuels-Determination of Total Content of Sulfur and Chlorine. ISO: Geneva, Switzerland, 2016.

46. Wiedmann, T.; Minx, J. A Definition of 'Carbon Footprint'. Science 2007, 1, 1-11.

47. ISO 14067:2018; Greenhouse Gases-Carbon Footprint of Products-Requirements and Guidelines for Quantification. ISO: Geneva, Switzerland, 2018.

48. ISO 14040:2006; Environmental Management-Life Cycle Assessment-Principles and Framework. ISO: Geneva, Switzerland, 2006

49. ISO 14044:2006; Environmental Management—Life Cycle Assessment—Requirements and Guidelines. ISO: Geneva, Switzerland, 2006.

50. Frischknecht, R.; Hischier, R.; Weidema, B.; Althaus, H.-J.; Bauer, C.; Doka, G.; Dones, R.; Hellweg, S.; Humbert, S.; Jungbluth, N.; et al. Implementation of Life Cycle Impact Assessment Methods Data v1.1 (2004). In Ecoinvent Report No. 3; Ecoinvent Centre: Dübendorf, Switzerland, 2004; p. 116.

51. Ivanova, N.; Gugleva, V.; Dobreva, M.; Pehlivanov, I.; Stefanov, S.; Andonova, V. Combustion of Biomass Fuel and Residues: Emissions Production Perspective. In Developments in Combustion Technology; Kyprianidis, K., Skvaril, J., Eds.; IntechOpen: London, UK, 2016; p. 31.

52. European Parliament Directive (EU). 2018/2001 of the European Parliament and of the Council on the promotion of the use of energy from renewable sources. Off. J. Eur. Union 2018, 2018, 82-209.

53. Commissione Europea. Comunicazione Della Commissione. Un Pianeta Pulito per Tutti; Commissione Europea: Bruxelles, Belgium, 2018.

54. Redcert GMBH. Scheme Principles for GHG Calculation; Version EU 05; Redcert GMBH: Bonn, Germany, 2021 ; pp. 5-7.

55. European Council. National overall targets for the share of energy from renewable sources in gross final consumption of energy in 2020. Share of energy from renewable sources in gross final consumption of energy, 2005 (S 2005). Target for share of energy from renewable sources. In Annex. 1 to 12. Proposal for a Directive of the European Parliament and of the Council on the Promotion of the Use of Energy from Renewable Sources; European Council: Brussels, Belgium, 2017; pp. 19-64.

56. Giuntoli, J.; Agostini, A.; Edwards, R.; Marelli, L. Solid and gaseous bioenergy pathways, Input values and GHG emissions: Calculated according to methodology set in COM (2010) 11 and SWD(2014) 259. In JRC Science and Policy Reports; European Commission: Brussels, Belgium, 2015.

57. Anukam, A.; Berghel, J. Biomass Pretreatment and Characterization: A Review. In Biotechnological Applications of Biomass; Basso, T., Basso, L.C., Eds.; IntechOpen: London, UK, 2020; Volume I, pp. 1-17, ISBN 978-1-83881-182-2.

58. Khan, A.A.; de Jong, W.; Jansens, P.J.; Spliethoff, H. Biomass combustion in fluidized bed boilers: Potential problems and remedies Fuel Process. Technol. 2009, 90, 21-50. [CrossRef]

59. Vassilev, S.V.; Vassileva, C.G.; Song, Y.C.; Li, W.Y.; Feng, J. Ash contents and ash-forming elements of biomass and their significance for solid biofuel combustion. Fuel 2017, 208, 377-409. [CrossRef]

60. Vakkilainen, E.K. Solid Biofuels and Combustion; Elsevier: Amsterdam, The Netherlands, 2017; ISBN 9780128043899.

61. García, R.; Pizarro, C.; Lavín, A.G.; Bueno, J.L. Characterization of Spanish biomass wastes for energy use. Bioresour. Technol. 2012, 103, 249-258. [CrossRef]

62. Saidur, R.; Abdelaziz, E.A.; Demirbas, A.; Hossain, M.S.; Mekhilef, S. A review on biomass as a fuel for boilers. Renew. Sustain. Energy Rev. 2011, 15, 2262-2289. [CrossRef]

63. Pergola, M.; Rita, A.; Tortora, A.; Castellaneta, M.; Borghetti, M.; De Franchi, A.S.; Lapolla, A.; Moretti, N.; Pecora, G.; Pierangeli, D.; et al. Identification of suitable areas for biomass power plant construction through environmental impact assessment of forest harvesting residues transportation. Energies 2020, 13, 2699. [CrossRef]

64. Butnar, I.; Rodrigo, J.; Gasol, C.M.; Castells, F. Life-cycle assessment of electricity from biomass: Case studies of two biocrops in Spain. Biomass Bioenergy 2010, 34, 1780-1788. [CrossRef]

65. Chary, K.; Aubin, J.; Guindé, L.; Sierra, J.; Blazy, J.M. Cultivating biomass locally or importing it? LCA of biomass provision scenarios for cleaner electricity production in a small tropical island. Biomass Bioenergy 2018, 110, 1-12. [CrossRef]

66. Lindholm, E.L.; Berg, S.; Hansson, P.A. Energy efficiency and the environmental impact of harvesting stumps and logging residues. Eur. J. For. Res. 2010, 129, 1223-1235. [CrossRef]

67. Cherubini, F.; Strømman, A.H. Life cycle assessment of bioenergy systems: State of the art and future challenges. Bioresour. Technol. 2011, 102, 437-451. [CrossRef]

68. Muench, S.; Guenther, E. A systematic review of bioenergy life cycle assessments. Appl. Energy 2013, 112, 257-273. [CrossRef]

69. Ganesh, A.; Banerjee, R. Biomass pyrolysis for power generation-A potential technology. Renew. Energy 2001, 22, 9-14. [CrossRef]

70. Bain, R.L.; Overend, R.P.; Craig, K.R. Biomass-fired power generation. Fuel Process. Technol. 1998, 54, 1-16. [CrossRef]

71. Evans, A.; Strezov, V.; Evans, T.J. Sustainability considerations for electricity generation from biomass. Renew. Sustain. Energy Rev. 2010, 14, 1419-1427. [CrossRef]

72. Loução, P.O.; Ribau, J.P.; Ferreira, A.F. Life cycle and decision analysis of electricity production from biomass-Portugal case study. Renew. Sustain. Energy Rev. 2019, 108, 452-480. [CrossRef]

73. Briones-Hidrovo, A.; Copa, J.; Tarelho, L.A.C.; Gonçalves, C.; Pacheco da Costa, T.; Dias, A.C. Environmental and energy performance of residual forest biomass for electricity generation: Gasification vs. combustion. J. Clean. Prod. 2021, 289, 125680. [CrossRef]

74. Rafaschieri, A.; Rapaccini, M.; Manfrida, G. Life cycle assessment of electricity production from poplar energy crops compared with conventional fossil fuels. Energy Convers. Manag. 1999, 40, 1477-1493. [CrossRef] 
75. Carpentieri, M.; Corti, A.; Lombardi, L. Life cycle assessment (LCA) of an integrated biomass gasification combined cycle (IBGCC) with $\mathrm{CO}_{2}$ removal. Energy Convers. Manag. 2005, 46, 1790-1808. [CrossRef]

76. Puy, N.; Rieradevall, J. Environmental assessment of post-consumer wood and forest residues gasification: The case study of Barcelona metropolitan area. Biomass Bioenergy 2010, 34, 1457-1465. [CrossRef]

77. Siegl, S.; Laaber, M.; Holubar, P. Green electricity from biomass, Part I: Environmental impacts of direct life cycle emissions. Waste Biomass Valoriz. 2011, 2, 267-284. [CrossRef]

78. Wang, C.; Zhang, L.; Yang, S.; Pang, M. A Hybrid Life-Cycle Assessment of Nonrenewable Energy and Greenhouse-Gas Emissions of a Village-Level Biomass Gasification Project in China. Energies 2012, 5, 2708-2723. [CrossRef]

79. Röder, M.; Whittaker, C.; Thornley, P. How certain are greenhouse gas reductions from bioenergy? Life cycle assessment and uncertainty analysis of wood pellet-to-electricity supply chains from forest residues. Biomass Bioenergy 2015, 79, 50-63. [CrossRef]

80. Paengjuntuek, W.; Boonmak, J.; Mungkalasiri, J. Environmental Assessment of Integrated Biomass Gasification Fuel Cell for Power Generation System. Int. J. Environ. Sci. Dev. 2015, 6, 445-450. [CrossRef]

81. Nian, V. The carbon neutrality of electricity generation from woody biomass and coal, a critical comparative evaluation. Appl. Energy 2016, 179, 1069-1080. [CrossRef]

82. da Costa, T.P.; Quinteiro, P.; Tarelho, L.A.; Arroja, L.; Dias, A.C. Environmental impacts of forest biomass-to-energy conversion technologies: Grate furnace vs. fluidised bed furnace. J. Clean. Prod. 2018, 171, 153-162. [CrossRef]

83. Yang, Q.; Zhou, H.; Zhang, X.; Nielsen, C.P.; Li, J.; Lu, X.; Yanga, H.; Chen, H. Hybrid life-cycle assessment for energy consumption and greenhouse gas emissions of a typical biomass gasification power plant in China. J. Clean. Prod. 2018, 205, 661-671. [CrossRef]

84. Siregar, K.; Luthfi Machsun, A.; Sholihati, S.; Alamsyah, R.; Ichwana, I.; Christian Siregar, N.; Syafriandi, S.; Sofiah, I.; Miharza, T.; Muhammad Nur, S.; et al. Life Cycle Impact Assessment on Electricity Production from Biomass Power Plant System through Life Cycle Assessment (LCA) Method using Biomass from Palm Oil Mill in Indonesia. E3S Web Conf. 2020, 188, 00018. [CrossRef]

85. Zang, G.; Zhang, J.; Jia, J.; Lora, E.S.; Ratner, A. Life cycle assessment of power-generation systems based on biomass integrated gasification combined cycles. Renew. Energy 2020, 149, 336-346. [CrossRef] 